\title{
SEPARATION AND DETERMINATION OF SIX METAL CATIONS BY CAPILLARY ZONE ELECTROPHORESIS
}

\author{
JINZHANG GAO*, XIANGLI SUN, WU YANG, HAIFENG FAN, CHONGYANG LI AND XUEFENG MAO
}

\author{
(Chemistry \& Chemical Engineering College, Northwest Normal University, Lanzhou 730070, P. R. China) \\ (Received: 18 May 2007 - Accepted: 11 January 2008)
}

\begin{abstract}
A rapid, simple and reliable method was devised for separation and determination of six metal cations, based on the capillary zone electrophoresis. The results showed that the complete separation of $\mathrm{K}^{+}, \mathrm{Cu}^{2+}, \mathrm{Zn}^{2+}, \mathrm{Mn}^{2+}, \mathrm{Pb}^{2+}$ and $\mathrm{Cd}^{2+}$ can be achieved within $5 \mathrm{~min}$. A new electrolyte system containing $15 \mathrm{mmol} \cdot \mathrm{L}^{-1}$ imidazole as a background absorbance reference and $8 \mathrm{mmol} \cdot \mathrm{L}^{-1}$ malonic acid, $2 \mathrm{mmol} \cdot \mathrm{L}^{-1} 18$-crown- 6 ether as the complexing agents, $10 \%$ methanol as an organic modifier, by using acetic acid to adjust the $\mathrm{pH}=4.40$ was developed. The applied voltage was $20 \mathrm{kV}$ at $25^{\circ} \mathrm{C}$. Under the optimum conditions, 6 ions were separated and determined with the correlation coefficient of $0.9984-0.9993$. The detection limits $(\mathrm{S} / \mathrm{N}=3)$ from $0.05\left(\mathrm{~K}^{+}\right)$to $0.75\left(\mathrm{Zn}^{2+}\right) \mathrm{mg} \cdot \mathrm{L}^{-1}$. The repeatability of migration times was less than $0.60 \%$ and of peak area ranged from 3.4 to $5.6 \%(n=6)$. The results were compared with AAS for analyzing the real samples of waste-water and snow water.
\end{abstract}

Keywords: Electrolyte composition; metal cations; capillary zone electrophoresis

\section{INTRODUCTION}

As a separation technique the capillary electrophoresis (CE) is extremely useful in organic analysis and has been used successfully in many areas. In marked contrast to the extensive studies of organic compounds, very few works of inorganic ions have been reported. The first paper concerning the indirection detection of inorganic ions by using CE was reported by Hjerten [1] in 1967. Since then, the application to the separation and determination of inorganic substances has developed rapidly and many papers have been published [2-3], in which the capillary zone electrophoresis (CZE) is one of the widely used capillary electrophoresis techniques, and some of critical reviews have been summarized [4-7]. The use of capillary zone electrophoresis for the analysis of cations in water samples has been studied [8-12]. In recent years, although many instrumental analysis have been used in environmental water samples, such as ion chromatography (IC) [13], atomic absorption spectroscopy (AAS) [14], as well as inductively coupled plasma combined with mass spectrometry (ICPMS) [15], the capillary zone electrophoresis holds the promise of even better separations and lower sample consumption [16]. Simultaneous determination of copper, cobalt and cadmium, manganese and lead were found to be influence by the derivative spectrophotometry [17]. For the purpose, in this paper a new electrolyte system contained $15 \mathrm{mmol} \cdot \mathrm{L}^{-1}$ imidazole as background absorbance reference, $8 \mathrm{mmol} \cdot \mathrm{L}^{-1}$ malonic acid and $2 \mathrm{mmol} \cdot \mathrm{L}^{-1} 18$-crown- 6 ether as the complexing agents, $10 \%$ methanol as an organic modifier, $\mathrm{pH}$ adjusted by acetic acid $(50 \%, \mathrm{~V} / \mathrm{V})$ to 4.40 was developed. The satisfactory results indicated that the proposed method could be used in water analysis.

\section{EXPERIMENTAL}

\subsection{Instrumentation}

Separation was performed on a P/ACE 5510 apparatus (Beckman Instruments, USA) equipped with a UV detector and wavelength filters (190, $200,214,254$ and $280 \mathrm{~nm}$ ). A fused silica capillary (total length $47 \mathrm{~cm}, 75 \mu \mathrm{m} . \mathrm{i}$ d; Yongnian Fiber Optic Factory, China) was used. The distance from the point of injection to the detection window was $40 \mathrm{~cm}$. Gold software System was used for data acquisition. A mode $211 \mathrm{pH}$-meter (HANNA, Italy) was used. Electromigration injection was carried out by using a voltage of $5 \mathrm{KV}$ for $5 \mathrm{~S}$. The separation temperature of $25^{\circ} \mathrm{C}$ and the applied separation voltage of 20 $\mathrm{kV}$ were used, respectively.

\subsection{Reagents and solutions}

All reagents were of analytical grade and used as received from Tianjin Chemical Reagent Factory, China. Imidazole and 18-crown-6 ether were obtained from Sigma (Sigma Chemical Co., St. Louis, MO, USA). All solutions and electrolytes were prepared with ultra-pure water from a Milli-Q system (Millipore, Germany). Stock standard solutions of various metal cations $\left(1 \mathrm{~g} \cdot \mathrm{L}^{-}\right.$ $\left.{ }^{1}\right)$ were obtained by dissolving their corresponding inorganic salts (nitrates, sulfates or chlorides), and stored in refrigerator prior to use.

\subsection{Procedures}

Before the use, the capillary was rinsed with $0.1 \mathrm{~mol} \cdot \mathrm{L}^{-1} \mathrm{NaOH}$ and ultrapure water for $5 \mathrm{~min}$, followed by the used carrier electrolyte for $10 \mathrm{~min}$. The capillary was rinsed for 2 min with carrier electrolyte between runs. All electrolytes and samples were filtered through a $0.45 \mu \mathrm{m}$ membrane filter and degassed by ultrasonication prior to analysis.

\section{RESULTS AND DISCUSSION}

In general, most inorganic anions and cations have no strong absorption in UV-visible spectral region. For improving the sensitivity, complex reactions are commonly used, that is, adding some complexing agent (such as $\alpha$-hydroxyisobutyric acid (HIBA), citrate, EDTA and acetic acid) into the electrolytic solution. If so, some factors in operation, e.g., the composition and concentration of buffer, $\mathrm{pH}$ adjustment as well as voltage and temperature, should be optimized in advance.

\subsection{Optimization of the running buffer}

The running buffer composition and concentration affect basically the sensitivity and selectivity. Padarauskas et al. [18] pointed out that the separation efficiency was proportional to running buffer concentration. The larger running buffer concentration, the higher separation efficiency. In this study, we use imidazole in buffer as the background absorption at $214 \mathrm{~nm}$ to examine the operation conditions. The influence of imidazole concentration was studied from 5 to $18 \mathrm{mmol} \cdot \mathrm{L}^{-1}$ while the background electrolyte (BGE) was at $\mathrm{pH}=4.40$. Too low concentration may broaden the cation peak to cause difficult in separation. With increasing the concentrations of electrolyte, a better resolution was observed. However, when the concentration of imidazole was over $15 \mathrm{mmol} \cdot \mathrm{L}^{-1}$, the large Joule heat would produce to make the baseline excursion. Thereby the suitable concentration of $15 \mathrm{mmol} \cdot \mathrm{L}^{-1}$ was chosen.

Generally, most of single cations are difficult to separate directly by CE, as their migration velocities are very close to each other. The use of some weak complexing agents, such as HIBA, malic, glycolic, tartaric and malonic, can improve the separation efficiency. In this study, malonic acid of $8 \mathrm{mmol} \cdot \mathrm{L}^{-1}$ was used for separating 6 cations, just showing in Figure 1.

Fig 1 shows that $\mathrm{K}^{+}$and $\mathrm{Mn}^{2+}$ cannot be complete baseline separation by using malonic acid only. Some papers reported $[16,19,20]$ that the addition of crown ether (18-crown-6 ether) could improve the selectivity. For improving the separation between $\mathrm{K}^{+}$and $\mathrm{Mn}^{2+}$ ions we investigated the effect of 18crown-6 ether on the separation showing in Figure 2. Results indicated that adding $2 \mathrm{mmol} \cdot \mathrm{L}^{-1}$ of 18 -crown- 6 ether in the electrolyte makes a good baseline separation for 6 cations within $5 \mathrm{~min}$. 


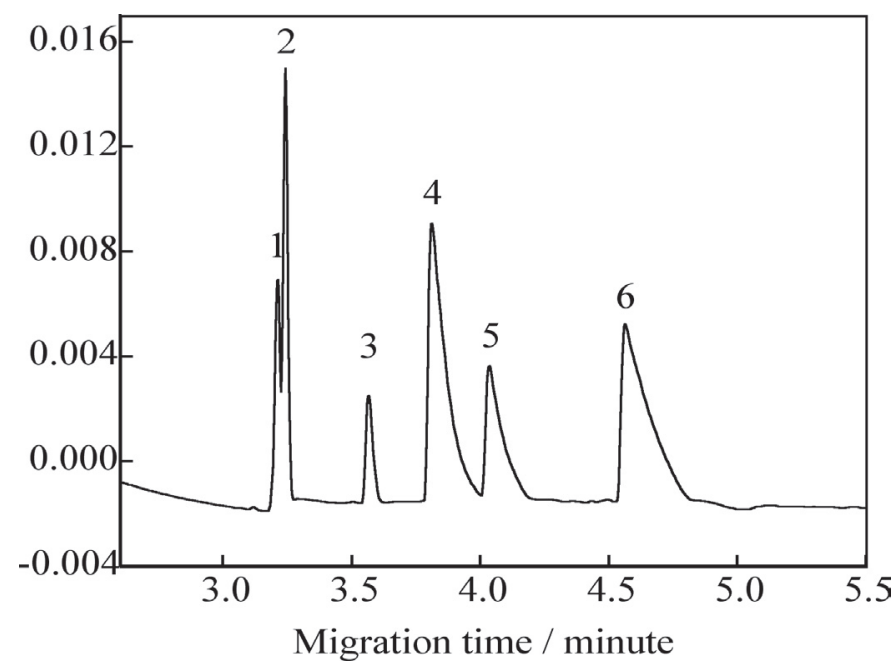

Figure 1. Electropherogram separation for 6 cations.

Electrolyte: $15 \mathrm{mmol} \cdot \mathrm{L}^{-1}$ imidazole, $8 \mathrm{mmol} \cdot \mathrm{L}^{-1}$ malonic acid, $\mathrm{pH} 4.40$.

Injection conditions: electromigration injection; $5 \mathrm{kV}, 5 \mathrm{~S}$. Separation voltage: $20 \mathrm{kV}$. Temperate: $25^{\circ} \mathrm{C}$. Indirect UV detection at $214 \mathrm{~nm}$.

1. $\mathrm{K}^{+} ; 2 . \mathrm{Mn}^{2+} ; 3 . \mathrm{Pb}^{2+} ; 4 . \mathrm{Cd}^{2+} ; 5 . \mathrm{Zn}^{2+} ; 6 . \mathrm{Cu}^{2+}$

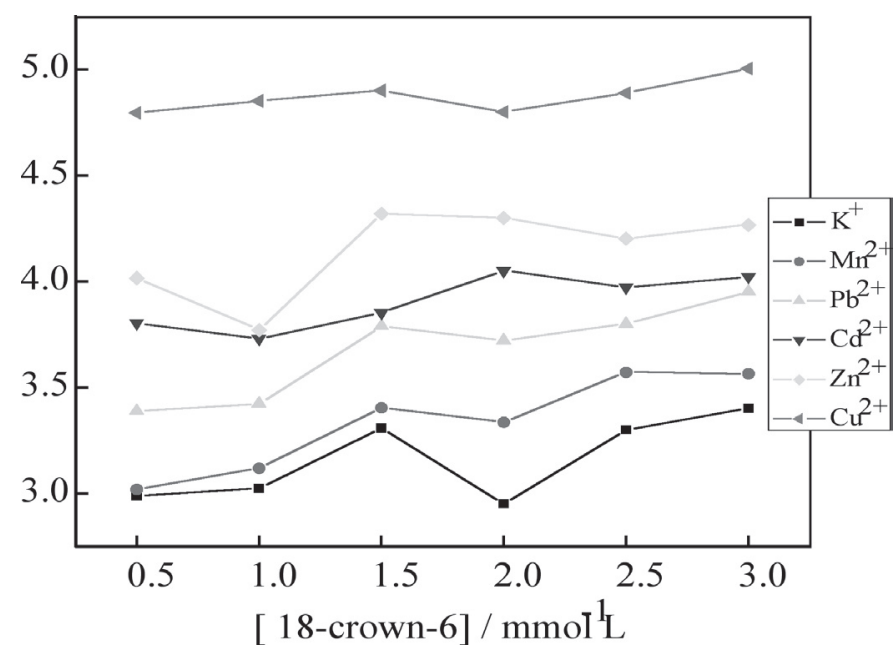

Figure.2. Effect of 18-crown -6 ether concentrations on the migration time of six metal cations.

Electrolyte: $15 \mathrm{mmol} \cdot \mathrm{L}^{-1}$ imidazole, $8 \mathrm{mmol} \cdot \mathrm{L}^{-1}$ malonic acid, $10 \%$ methanol, $\mathrm{pH} 4.40$.

Injection conditions and time as same in Figure 1.

In the pre-experimental, the addition of methanol was found to improve the property of electrolyte solution. In this study, $10 \%$ of methanol was suitable. More or less than the value would decrease the separation efficiency.

\section{2. pH of the running buffer}

The separation of metal cations should carry out in acidic media, due to the precipitation of heavy metal ions being formed in basic solutions [12] Moreover, the electroosmotic flow (EOF) can be affected by the $\mathrm{pH}$ of running buffer. In the experimental, the effect of $\mathrm{pH}$ on the sensitivity was studied in the range of 3.80-4.80. If the $\mathrm{pH}$ were less than 3.80 , the separation between $\mathrm{Pb}^{2+}$ and $\mathrm{Cd}^{2+}$ would be difficult; more than $\mathrm{pH} 4.40$, the migration time would be prolonged and the noise dramatically increased. As shown in Figure 3, the optimum condition was chosen at $\mathrm{pH}=4.40$.

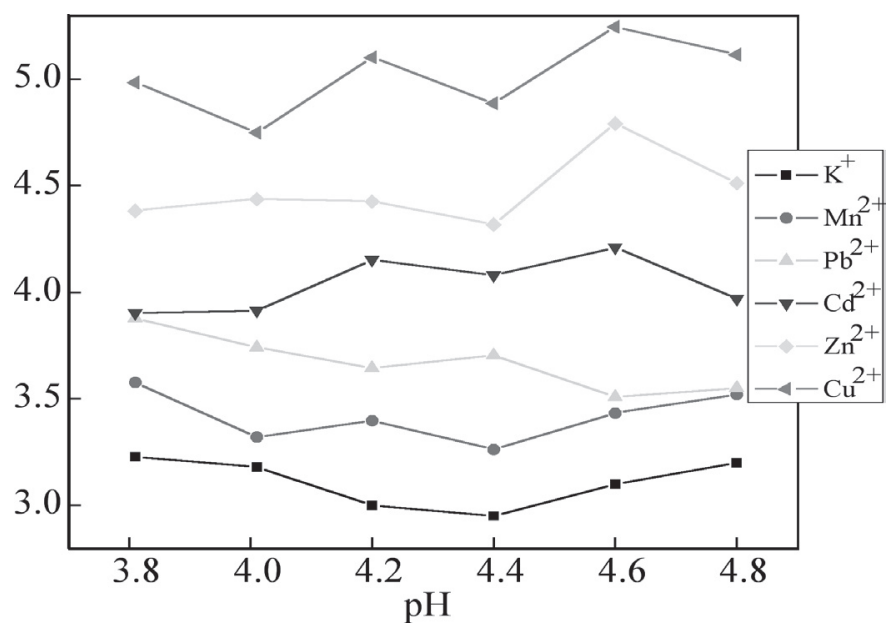

Fig.3. Effect of electrolyte $\mathrm{pH}$ on the migration time of six cations.

Electrolyte: $15 \mathrm{mmol} \cdot \mathrm{L}^{-1}$ imidazole, $8 \mathrm{mmol} \cdot \mathrm{L}^{-1}$ malonic acid, $2 \mathrm{mmol} \cdot \mathrm{L}^{-1}$ 18-crown-6 ether $10 \%$ methanol, $\mathrm{pH} 4.40$.

Injection conditions and time, the same as in Figure 1.

\subsection{Choice of voltage and temperature}

Generally, both applied voltage and temperature affect migration time of ions in electrolyte. With increasing the applied voltage the migration time of ions shortens; the higher temperature could also cause the migration time to be short. That is to say, under higher voltage and temperature the speed of ions would be faster. However, high voltage can cause the Joule-heat formed to raise temperature, and higher temperature gives a bad repeatability. A suitable way $\left(20 \mathrm{kV}\right.$ at $\left.25^{\circ} \mathrm{C}\right)$ in the study was adopted. As shown in Figure 4, under the chosen conditions, a complete baseline separation for 6 ions $\left(\mathrm{K}^{+}, \mathrm{Cu}^{2+}, \mathrm{Zn}^{2+}\right.$, $\mathrm{Mn}^{2+}, \mathrm{Pb}^{2+}$ and $\mathrm{Cd}^{2+}$ with $10 \mathrm{mg} \cdot \mathrm{L}^{-1}$ ) was done within $5 \mathrm{~min}$.

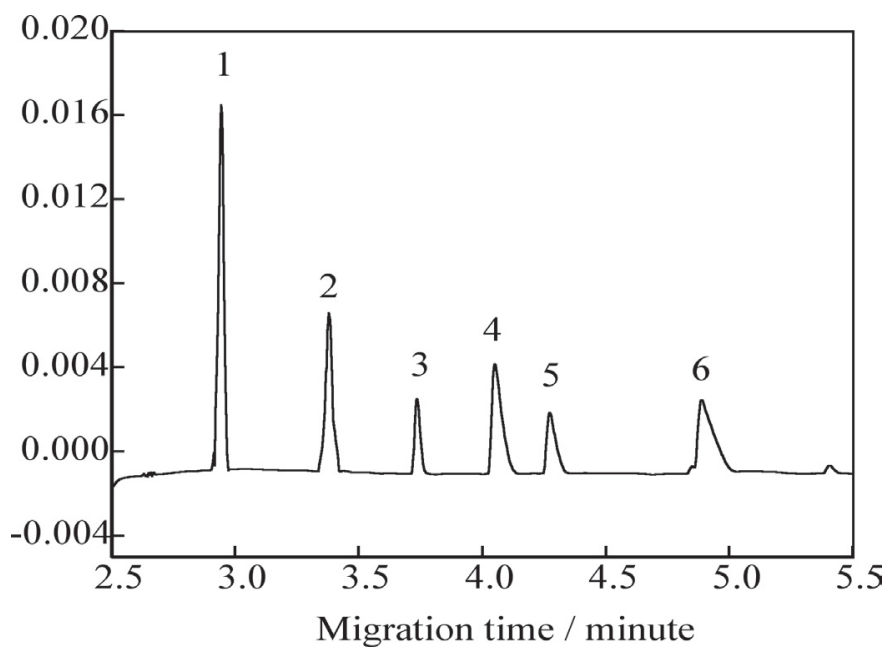

Figure 4. Separation of a standard cations mixture.

Electrolyte: $15 \mathrm{mmmol} \cdot \mathrm{L}^{-1}$ imidazole, $8 \mathrm{mmol} \cdot \mathrm{L}^{-1}$ malonic acid, $2 \mathrm{mmol} \cdot \mathrm{L}-$ ${ }^{1}$ 18-crown-6 ether and $10 \%(\mathrm{~V} / \mathrm{V})$ methanol; $\mathrm{pH} 4.40$; Voltage: $+20 \mathrm{kV}$; Temperate: $25^{\circ} \mathrm{C}$; electromigration injection $(5 \mathrm{kV}, 5 \mathrm{~S})$; indirect $\mathrm{UV}$ detection at $214 \mathrm{~nm}$.

$1 . \mathrm{K}^{+} ; 2 . \mathrm{Mn}^{2+} ; 3 . \mathrm{Pb}^{2+} ; 4 . \mathrm{Cd}^{2+} ; 5 . \mathrm{Zn}^{2+} ; 6 . \mathrm{Cu}^{2+}$

\subsection{Quantitative analysis}

Under the proposed conditions, a mixture containing 6 metal ions was detected. The linear range, detection limit and correlation coefficient are listed in Table 1. To ensure the corrected data mentioned above, each point was detected in triplicate. The correlation coefficients were limited from 0.9984 to 0.9993 . Limit of detection (LOD) was defined as the analyte concentrations corresponding to a signal equal to three times the background noise $(\mathrm{S} / \mathrm{N}=3)$, which were found to be from 0.05 to $0.75 \mathrm{mg} \cdot \mathrm{L}^{-1}$. 
Table 1.- Determination limit (LOD) and correlation coefficient (r) of cations analyses

\begin{tabular}{ccccc}
\hline Analytes & $\begin{array}{c}\text { Limit of } \\
\text { detection } \\
(\mathrm{LOD}) \\
\left(\mathrm{mg} \cdot \mathrm{L}^{-1}\right)\end{array}$ & $\begin{array}{c}\text { Linear range } \\
\left(\mathrm{mg} \cdot \mathrm{L}^{-1}\right)\end{array}$ & $\begin{array}{c}\text { Correlation } \\
\text { coefficient }(\mathrm{r})\end{array}$ \\
\cline { 2 - 4 } $\mathrm{K}^{+}$ & 0.05 & $0.5-30$ & 0.9986 \\
$\mathrm{Cu}^{2+}$ & 0.05 & & $0.2-30$ & 0.9993 \\
${^{2+}} }$ & 0.75 & $1-30$ & 0.9991 \\
\hline $\mathrm{Mn}^{2+}$ & 0.1 & $0.2-30$ & 0.9987 \\
$\mathrm{Cd}^{2+}$ & 0.1 & $1-32$ & 0.9984 \\
$\mathrm{~Pb}^{2+}$ & 0.1 & $0.5-20$ & 0.9989 \\
\hline
\end{tabular}

The repeatability of the proposed method was evaluated by a standard solution containing 6 ions with $5 \mathrm{mg} \cdot \mathrm{L}^{-1}$; which was determined repeatedly for 8 times. Table 2 indicated that the relative standard deviation (RSD) of peak area was ranged from $3.4 \%$ to $5.6 \%$.

Table 2.- Relative standard deviations (RSD) of Migration times and Peak area $(\mathrm{n}=8)$.

\begin{tabular}{ccc}
\hline Analytes & $\begin{array}{c}\text { Migration time (RSD, } \\
\%)\end{array}$ & Peak area (RSD, \%) \\
\hline $\mathrm{K}^{+}$ & 0.33 & 4.8 \\
\hline $\mathrm{Cu}^{2+}$ & 0.42 & 5.6 \\
\hline $\mathrm{Zn}^{2+}$ & 0.55 & 3.9 \\
\hline $\mathrm{Mn}^{2+}$ & 0.36 & 3.7 \\
$\mathrm{Cd}^{2+}$ & 0.39 & 3.4 \\
$\mathrm{~Pb}^{2+}$ & 0.47 & 4.4 \\
\hline
\end{tabular}

Under the optimum conditions, some of real samples, such as wastewater and snow water, were examine by the proposed method. The data obtained by CZE are in good agreement with those detected by atomic absorption spectrometry (AAS). Moreover, the recovery test was also carried out with the satisfactory results. All results are given in Figure 5, Table 3 and Table 4.

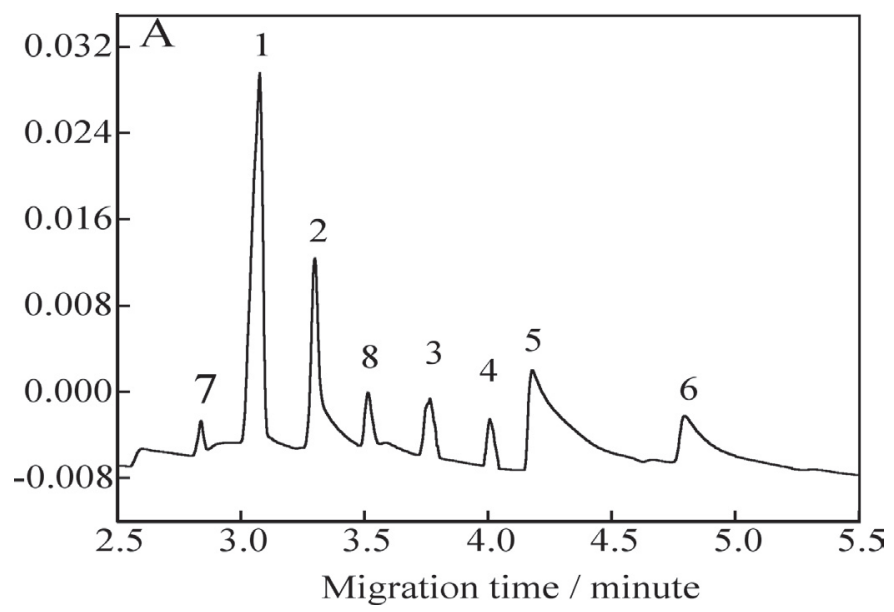

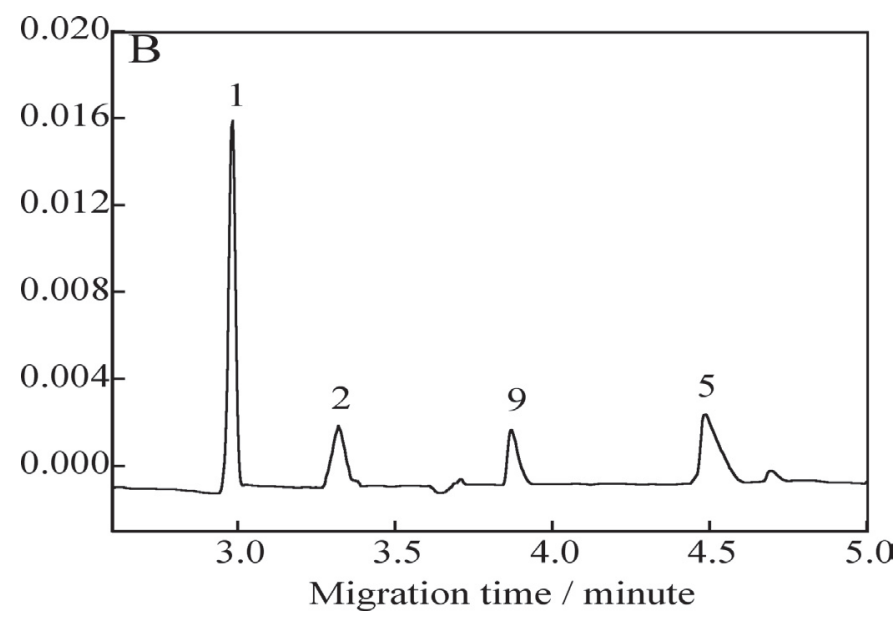

Figure.5. Electropherogram of the cations in

(A) waste water and (B) snow water samples with proposed method.

Experimental conditions: the same as in Fig. 4.

1. $\mathrm{K}^{+} ; 2 . \mathrm{Mn}^{2+} ; 3 . \mathrm{Pb}^{2+} ; 4 . \mathrm{Cd}^{2+} ; 5 . \mathrm{Zn}^{2+} ; 6 . \mathrm{Cu}^{2+} ; 7 . \mathrm{NH}_{4}^{+} ; 8 . \mathrm{Ni}^{2+} ; 9 . \mathrm{Co}^{2+}$;

Table 3: Analytic results of six metal cations in the water samples. (Unit: $\left.\mathrm{mg} \cdot \mathrm{L}^{-1}\right)$

\begin{tabular}{|c|c|c|c|}
\hline Samples & Element & $\begin{array}{c}\text { Found by } \\
\text { CZE }\end{array}$ & Found by AAS \\
\hline \multirow[t]{8}{*}{ Waste water } & $\mathrm{K}+$ & 7.96 & 7.92 \\
\hline & $\mathrm{Cu}^{2+}$ & 2.21 & 2.27 \\
\hline & $\mathrm{Zn}^{2+}$ & 3.46 & 3.40 \\
\hline & $\mathrm{Mn}^{2+}$ & 0.88 & 0.91 \\
\hline & $\mathrm{Cd}^{2+}$ & 1.12 & 1.07 \\
\hline & $\mathrm{Pb}^{2+}$ & 1.51 & 1.58 \\
\hline & $\mathrm{NH}_{4}^{+*}$ & 0.23 & \\
\hline & $\mathrm{Ni}^{i^{2+*}}$ & 0.66 & \\
\hline \multirow{7}{*}{ Snow water } & $\mathrm{K}^{+}$ & 8.80 & 8.76 \\
\hline & $\mathrm{Cu}^{2+}$ & ND & 0.12 \\
\hline & $\mathrm{Zn}^{2+}$ & 1.08 & 1.13 \\
\hline & $\mathrm{Mn}^{2+}$ & 0.34 & 0.30 \\
\hline & $\mathrm{Cd}^{2+}$ & ND & ND \\
\hline & $\mathrm{Pb}^{2+}$ & ND & ND \\
\hline & $\mathrm{Co}^{2+*}$ & 0.10 & \\
\hline
\end{tabular}

*: semi-quantive; ND means that this ion has not been found by using CZE and/or AAS techniques.

Table 4.- Recoveries (\%) obtained by the method of standard additions for analyzed cations in snow water.

\begin{tabular}{|c|c|c|c|}
\hline Cations & $\begin{array}{l}\text { Added amount } \\
\left(\mathrm{mg} \cdot \mathrm{L}^{-1}\right)\end{array}$ & $\begin{array}{l}\text { Found amount } \\
\left(\mathrm{mg} \cdot \mathrm{L}^{-1}\right)\end{array}$ & Recovery (\%) \\
\hline $\mathrm{K}^{+}$ & 5.00 & 13.52 & 94.4 \\
\hline $\mathrm{Cu}^{2+}$ & 5.00 & 4.92 & 98.4 \\
\hline $\mathrm{Zn}^{2+}$ & 5.00 & 6.10 & 100.4 \\
\hline $\mathrm{Mn}^{2+}$ & 5.00 & 5.33 & 99.8 \\
\hline $\mathrm{Cd}^{2+}$ & 5.00 & 4.88 & 97.6 \\
\hline $\mathrm{Pb}^{2+}$ & 5.00 & 5.04 & 100.8 \\
\hline
\end{tabular}




\section{CONCLUSIONS}

Although capillary zone electrophoresis is used to determining the organic compounds, the application to inorganic ions is quite successful, too. In this paper, we studied the separation of 6 ions by CZE. The background electrolyte consists of $15 \mathrm{mmol} \cdot \mathrm{L}^{-1}$ imidazole, $8 \mathrm{mmol} \cdot \mathrm{L}^{-1}$ malonic acid, $2 \mathrm{mmol} \cdot \mathrm{L}^{-1} 18$ crown-6 ether, and $10 \%$ methanol. The $\mathrm{pH}$ of solution was 4.40 at $25^{\circ} \mathrm{C}$ and applied voltage $20 \mathrm{kV}$. Under conditions, 6 metal-ions in real samples were separated and detected successfully within $5 \mathrm{~min}$. The proposed method can be used in environmental analysis.

\section{ACKNOWLEDGEMENTS}

This work was supported in part by the Natural Science Foundation of Gansu Province (3ZS041-A25-028), the Invention Project of Science \& Technology (KJCXGC-01, NWNU), and the Key Lab of Polymer Materials of Gansu Province, China.

\section{REFERENCE}

[1] Hjerten, S., Free zone electrophoresis, Chromatographic Reviews, (1967), 9: $122-219$

[2] Hopper, K.G., LeClair, H., McCord, B.R., A novel method for analysis of explosives residue by simultaneous detection of anions and cations via capillary zone electrophoresis, Talanta, (2005), 67: 304-312

[3] Bazzanella, A., Lochmann, H., Tomos, A.D., Bachmann, K., Determination of inorganic cations and anions in single plant cells by capillary zone electrophoresis, Journal of Chromatography A, (1998), 809: 231-239

[4] Pacakova, V., Coufal, P., Stulik, K., Capillary electrophoresis of inorganic cations, Journal of Chromatography A, (1999), 834: 257-275

[5] Fukushi, K., Takeda, S., Chayama, K., Application of capillary electrophoresis to the analysis of inorganic ions in environmental samples, Journal of Chromatography A, (1999), 834: 349-362

[6] Valsecchi, S.M., Polesello, S., Analysis of inorganic species in environmental samples by capillary electrophoresis, Journal of Chromatography A, (1999), 834: 363-385

[7] Sadecka, J., Polonsky, J., Determination of inorganic ions in food and beverages by capillary electrophoresis, Journal of Chromatography A, (1999), 834: 401-417

[8] Tangen, A., Lund, W., Frederiksen, R.B., Determination of $\mathrm{Na}^{+}, \mathrm{K}^{+}$, $\mathrm{Mg}^{2+}$ and $\mathrm{Ca}^{2+}$ in mixtures of seawater and formation water by capillary electrophoresis, Journal of Chromatography A, (1997), 767: 311-317

[9] Haumann, I., Boden, J., Mainka, A., Jegle, U., Simultaneous determination of inorganic anions and cations by capillary electrophoresis with indirect UV detection, Journal of Chromatography A, (2000), 895: 269-277

[10] Padarauskas, A., Olsauskaite, V., Schwedt, G., Simultaneous separation of inorganic anions and cations by capillary zone electrophoresis, Journal of Chromatography A, (1998), 800: 369-375

[11] Padarauskas, A., Olsauskaite, V., Paliulionyte, V., Simultaneous determination of inorganic anions and cations in waters by capillary zone electrophoresis, Journal of Chromatography A, (1998), 829: 359-365

[12] Kuban, P., Karlberg, B., Simultaneous determination of small cations and anions by capillary electrophoresis, Analytical. Chemistry, (1998), 70: 360-365

[13] Peter E., Jackson, Determination of inorganic ions in drinking water by ion chromatography, Analytical Chemistry, (2001), 20: 320-329

[14] Sun J.M., Xu P., Sun H.W., Determiantion of Cu (II), Zn (II), Co (II) , Ni (II), $\mathrm{Pb}$ (II) and $\mathrm{Cd}$ (II) by Chitosan Separation-Flame Atomic Absorption Spectrometry, Chinese Journal of Analytical Chemistry (Ch.), (2004), 32: 1356-1358

[15] Rahmi, D., Zhu, Y.B., Fujimori, E., Umemura, T., Haraguchi, H., Multielement determination of trace metals in seawater by ICP-MS with aid of down-sized chelating resin-packed minicolumn for preconcentration, Talanta, (2007), 72: 600-606

[16] Fung, Y.S., Lau, K.M., Separation and determination of cations in beverage products by capillary zone electrophoresis, Journal of Chromatography A, (2006), 118: $144-150$

[17] Xiao X.L., Liu RX., Zhang S.F., Third derivative spectrophometric simultaneous determination of copper, cobalt and cadmium, chinese Journal of Applied chemistry (Ch), (1995), 12: 50-53

[18] Padarauskas, A., Olsauskaite, V., Paliulionyte, V., New electrolyte system for the determination of ammonium, alkali and alkaline earth cations by capillary electrophoresis, Analytica Chimica Acta, (1998), 374: 159-165

[19] Pantsar-Kallio, M., Manninen, P.K.G., Determination of sodium, potassium, calcium and magnesium cations by capillary electrophoresis compared with ion chromatography, Analytica Chimica Acta, (1995), 314: $67-75$

[20] Fung, Y.S., Lau, K.M., Tung, H.S., Analysis of leachable and total trace metals in air particulate matters by capillary electrophoresis, Talanta, (1998), 45: 619-629 